\title{
高速卷返機に関する研究(第2 郝)
}

\section{一パッケージ（卷玉）についでー}

(昭和 25 年11月 8 日受理)

\section{1. 緒言}

第 1 報において、参系速度と生㲜量の閔係につ いて述べたが、生產の目的物である卷玉一多く の場合卷返機の原料も又同時に卷玉であるがの形式形狀は、用途によつて限定されると共に、 その樣態の如何によつては、卷返速度や生暧量に つんてはんらまでもなく、最終製品の品質、後続作 業の能率に重大影響を及姑するのである。本報 は、主として紡績において用いられる形式の卷玉 につんて、理論的考察の概要を述べたものである。

\section{2. 卷玉の基本的要件}

紡績におんて、卷玉として要求せられる主度る 必要條件は、次の如くである。

1. 参玉の卷杘に際して、定常的禾速において は、その糸速の迎速にか小わらす、その張力は終 始一貫一定であつて、張力の変動、切激等の秀い と。

2. 又仅に糸の卷杘速度にか子り急激存変動が あつても、一系を急に停止し又引出しても一 これがために支障があつたり、特別の施設を必要 としないてと。

3. 糹はなるべく最小の張力において卷戾しう る方がよい。從つて、卷戻のために必要とされる 卷芯や参玉の回転抵抗力や、その慣性回転を防ぐ ための制動力等があることは好ましくなく、邓糸 が糸㻺中に喰ん込んだり、卷杘のために空氣抵抗 力や重力のか」ることも、原則としては望ましく 存的。

しかし一方人絹糸卷玉の如く、放置しておけば 自然に卷戾してしまう場合があるのも困るので、 極小さん一定の卷戻抵抗があるてとは䌸ましい。
会員唐。沢。惟儀***

4. 兊玉を卷返す時には、綾振幅の位置の如何 に係らず、又形成した糸愿の厚さの如何に係らず 质るべく一定の糸速で卷上げられ、且張为に変動 のないことが望ましい。

5. 卷返しの時の糸の張力は、一般的には、糸。 の彈性的限度以下であるてとを紫さ場合が多い。 杀の張力が降伏点を超えると、所謂糸が死ぬとい つて、糸の强力が低下したり、番手が変つたりす るからである。しかし場合によつては、降伏点近 傍乃至はてれを超える張力をかけることによつ て、撚りや番手の局部的不均一性を除去したり、 逆に强力を堆進したり、一層細番手の優良糸を生 產する手段とすることもある。乙れ等種ふの要求。 に應して、その張力を変えても支障のなんことが 望ましい。

6. 卷返しに際して、糸が毛犲立つたり、摩擦、 屈曲、压迫等によつて、系質强度を損 5虞のない こと。

7. ネツプ、塺埃、夾雜物、綿埃等の混入しが たんとと。

8. 卷玉の各部の密度、宾陴率、彈性、堅さ等 る、卷玉の大小、內外を問わ亦原則として、なる べく均一质ること。

-9. 空吵の殆んどない所謂閉式卷（クローズ・ ワインド）と、管染色等に希望される空㗂を極め て多量に必要とする所謂開式赏（ボープン・ワイ ンド）とが、或は種くの密度のものが、その使用 目的に應じて、同一の卷返機の僅かの改変調整に よつて、任意且容易に製造し得るてと。

10. 一定禾量の牵玉が、最小の容積重量に簡易 安價迅速に荷造され、輸揆中に加えられる外力に 一対して、改裝の有無强弱に係らず、型崩れ変形し て、外観を損したり、卷戻に際して支障を生し難

* On the High Speed Winders. Report 2: Theory of Package.

***昭和25年10月14日関西工学連合会にて発表

*** Koreyosi Karasawa, Member. 
いてと。

11. 春玉芯棒としては、なるべく小さく簡 單を形狀のもので、特殊の資材を用ん和、安 價大量飞生產され、水浸、加熱、乾燥や屈曲、 压迫等の外力を受けても狂い、破損、劣化し 難い軽量强力子ものを使用し得ること。

出來得れば兊芯を使用しないか、卷上後取 除いても差支え教い方がよいが、系本來の性 質からてれはあまり期待出來ね場合が多い。

12.参玉のま小でも商品價值のあるよ5美 観をそなえるてと。

以上要約すれば、系の大部分は織物とする のであるから、織物として又織布作業上に適 当な形式形狀のものがよいというとと质 る。てれ等の各項については、一應常識的に 知られている事柄も多いので、高速然返機の 生產対照として考慮すべき若干の点につんて のみ敘述するてととしたん。

\section{3. 卷玉の形式}

現在一般に使用せられでいる卷玉と芯管の 形式を分類すると、第1表に示された要目に
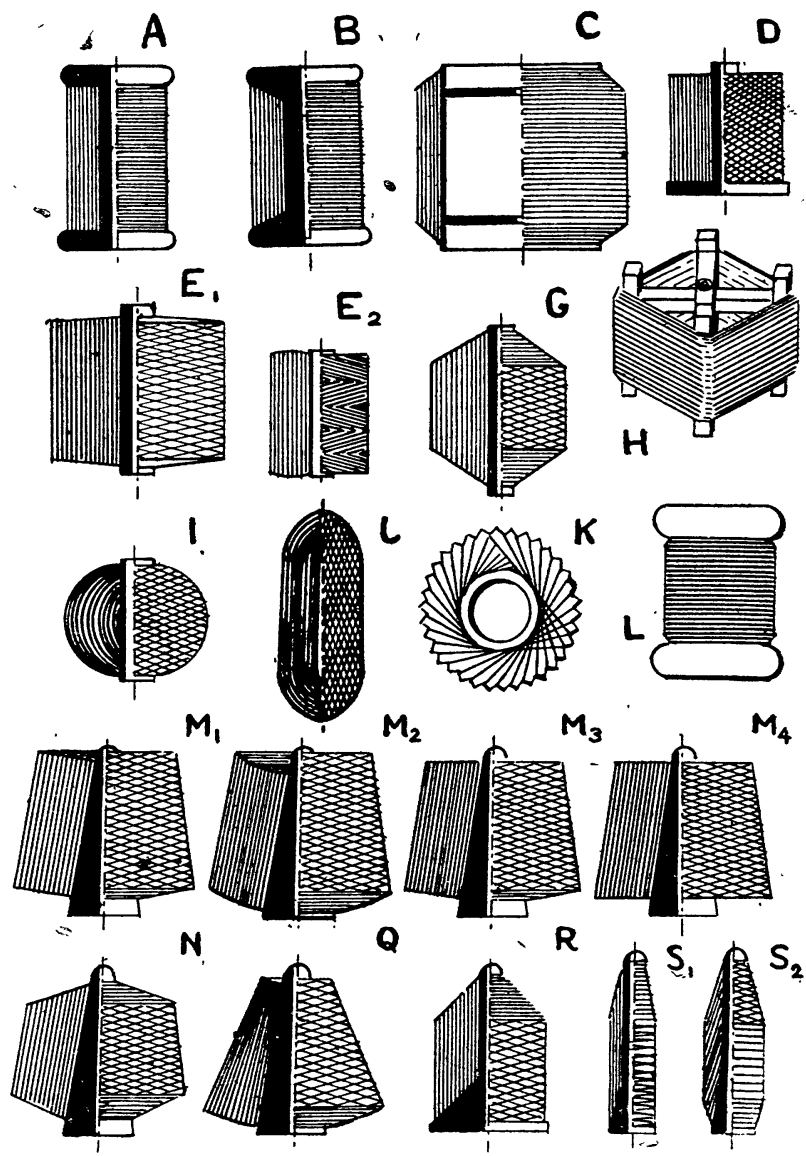

\begin{tabular}{|c|c|c|}
\hline & 系撩付角 & 1. 直行型(觕二小) 2 . 交錯型(角二大) \\
\hline ト & 系 間 隔 & 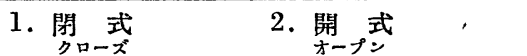 \\
\hline $\begin{array}{l}\text { バ } \\
1\end{array}$ & 分 割 法 & $\begin{array}{l}\text { 1. 等角割 } 2 \text {. 等 毞 割 } \\
\text { 3. 不定割 } \\
\text { イレキンラー }\end{array}$ \\
\hline ス & 綾振 幅 & $\begin{array}{l}\text { 1. 漸大 2. - 定(略一定) 3. 漸小 } \\
\text { 4. 周期的変化 }\end{array}$ \\
\hline 種 & & 1. 縱長(幅廣) 2. 中間 3. 縱薄(幅狄) \\
\hline 類 & 糸 層 厚 & 1. 定 厚 \\
\hline & & 1. 定位置 2. 漸進移動 3. 往復移動 \\
\hline 兴玉 & 断面形狀 & 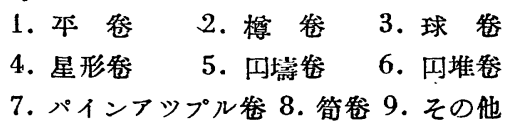 \\
\hline & \multirow{3}{*}{ 芯 } & 2. 無 芯 \\
\hline & & 1. 両緣付 \\
\hline & & 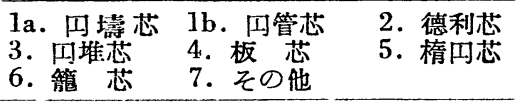 \\
\hline 用 & 途 & 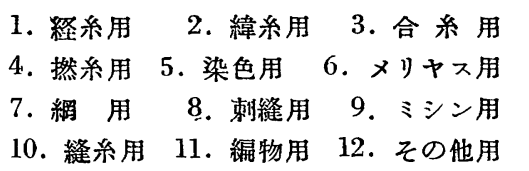 \\
\hline
\end{tabular}

別けられ、これらの組合せとよつて、理論的には 相当多種類の型式が可能であるが、実用に多く供 せられているものは、大小太細等は别として、形 式的には第 2 亿例示された程度で、左程多くは 少いて。

れらの四と表につんて一ß解說するてとは省略 させて戴く。たがとの表中 "分割法”というのは 軸芯周面を系によつて如何なる分割方法をとりつ 小卷玉が成長するかというてとであつて、卷玉の 大小に係らず、相重质る系の軌跡が中心線に対し て一定角を索するのを等角割といっ、相重索る糸 の軌跡を中心線よりみる角が常に一定のものを等 比割とい5。師ち一周期間の糸の軌跡の展開図形 が、その位置の如何に係らず互に合同なるのを等 角割とい」、相隣るもののみが殆んど合同であつ て、一周面に常に一定数に分散しているものを等 比割という。

振幅が周期的に変化するものは、現在実際には 使用されていないようであるが、第 2 図Qの不等 
厚コーン卷を、数種の、或は漸変的に、振幅の変 化する綾振運動を組合せて形成する外國特許例が ある。

振幅の位、置が定位。置で、卷玉が成長するという ことは、嚴密には相重度る各層面が、最初の層面 佀立てた法線束と直交するてとであるが、便宣的 に尞玉の芯軸若くはクレードル支持軸が卷玉の成 長につれて特別を橫移動をせ奴際等にもいわれて いる。

\section{4. 卷戻の張 カ}

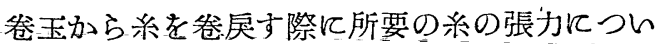
ては、多少研究されているてとであるが、卷返機 几関係して必要存考察を若干附加しておきたい。

卷杘の際の糹飞張力を生和る原因としては

$\tau_{\mathrm{a}}$ ：糸愿から糸が離脫すると要する力

$\tau \mathrm{b}$ : 糸の加速に要する力

$\tau_{\mathrm{c}}$ ：卷玉を卷杘すための糸の張力によつて回転 させた際に要する力

$\tau_{\mathrm{d}}$ : 糸が族転（バルーニング）する際に生ずる 遠心力之空氣抵抗に上つて生和る力

$\tau_{\mathrm{e}}$ ：系に作用する重力によつて生ずる力

$\tau_{\text {f }}$ : 糸が芯管緣、その他の物体之摩擦するとき 几生亦る力

$\tau_{\mathrm{g}}$ ：綾振りと卷返速度の変化飞原因する張力 （後報参照）

が主度るものであつて、てれらは卷玉の形式寸法 と、その卷杘の方法によつて、その有無度合が異 る。

てa）系の離脫抵抗：離脫抵抗を構成するもの はイ）糸表面の毛犽、凹凸、翏質物のために、 糸之系とが互に附着し、からみ合つているために 起る分離力。口) 下層の糸列間に喰込んでいるて とに原因する相互の摩擦力。八) 卷戻する杀の運 動方向に接触する糸層之卷杘系間に起る摩擦力。 ））卷玉內の糸の残留張力に上る糸の收縮運動や 卷玉の膨脹力に原因する相互の運動。ホ）糸の運 動方向に應するための彈性的屈曲変形に要する力 一等である。てれらの力の大体の價を、実驗礼よ つて求めてみると

綿茨・スフ䒺 $(20$ 's〜40's)

糸層飞垂直の方向人引出す時 $0.2 \sim 0.8 \mathrm{gr}$. 系層面に接触しつ」引出寸時 $0.5 \sim 5.0 \mathrm{gr}$.
毛糸 $(\sim 1 / 10)$

杀愿に垂直の方向

$0.5 \sim 3.0 \mathrm{gr}$

人絹 $(100 \mathrm{~d} \sim 200 \mathrm{~d})$

毛犽立な系 - $-1.0 \sim 0.2 \mathrm{gr}$.

程度がイ、シ、ホ項が主力となつた極端索喰込の ない場合の值である。值としては比較的小さいが 変動の多いてとが特徴であるため理論的解析の意 義を減する。又上記のように、糸層面を系が擦る 場合之擦らぬ場合では数倍の相違があるから、所 謂リポン卷が卷玉內に西る時は、卷杘に際して張 力変動が大をく、切断し存いまでも、網目が不揃 い反存つたり、はづれる原因となる。

、一喰込系には、枩玉の側压に対應する摩擦力之引 出し方向原因する摩擦力が作用して、裏系（綾 はづれともい5。Back-wound) のある場合と共 に、糸の抗張力以上の異常張力が発生して、系は 破断されるにいたる。

\section{$\tau$ b.) 系の加速に要する張力 :}

$\tau_{\mathrm{b}}=r_{l} \mathrm{~S}^{2} / 2 \fallingdotseq \mathrm{s}^{2} / 330 \mathrm{C}$, 但 $\mathrm{gr} . \mathrm{cm} / \mathrm{sec}^{2} \cdots(10)$ である。 20 番手綿糸、 $\mathrm{s}=600 \mathrm{~m} / \mathrm{min}$ では、て $1.5 \mathrm{gr}$ 程度である。

$\tau$ c）卷玉を回轉させる張力：芯軸の回転抵抗 や卷玉の回転空氣抵抗を除外した卷玉の回転慣性 に原因する張力は、卷玉內密度を均一と見做すと

$$
\tau_{\mathrm{c} 1}=\frac{w_{\mathrm{p}}}{\mathrm{g}} \frac{\mathrm{ds}}{\mathrm{dt}} \frac{\mathrm{k}_{\mathrm{p}}}{\mathrm{r}_{2}} \fallingdotseq \frac{\mathrm{w}_{\mathrm{p}}}{2} \frac{\mathrm{ds}}{\mathrm{d} \mathrm{g}}, \cdots
$$

となる。今 $\mathrm{w}_{\mathrm{p}}=1,000 \mathrm{gr}, \mathrm{ds} / \mathrm{dt}=60 \mathrm{~m} / \mathrm{min} / \mathrm{sec}$ とすると $\tau_{\mathrm{c} 1}=72 \mathrm{gr}$. と存り相当大きな張力が器 生和ることが判る。從つて旧式の整経機のように 尞玉を回転する方式では、300 1,000 m/min と いつた高速に杀を卷戻するてとは、ての点から到 底出來存い相談である。

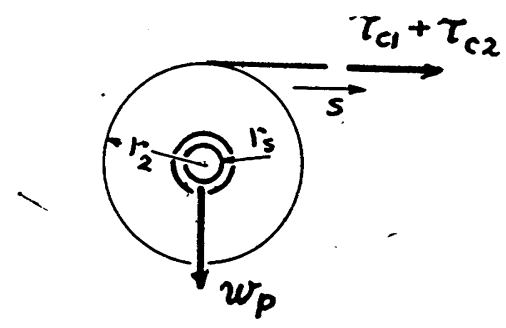

第 3 図

芯軸の回転のためと要する系の張力は

$$
\tau \mathrm{c}: 2 \fallingdotseq \mu_{\mathrm{s}} \mathrm{w}_{\mathrm{p}} \mathrm{r}_{\mathrm{s}} / \mathrm{r}_{2}
$$

となり、 $\mu_{\mathrm{s}}=0.3, \mathrm{r}_{\mathrm{s}}=0.4 \mathrm{~cm}$ の場合に $\tau_{\mathrm{c}: 2} \fallingdotseq 12 \mathrm{gr}$ で、先の加速回転に要する張力に比較すれば稍小 
さんが、なお相当の量である。

$\tau_{\mathrm{c} 2}$ の張力は、又卷返機の糸の卷取機構として、 卷玉に接する円筒によつて回転を與える際の、接 触摩擦力の一大部分飞概当する。又卷玉が所謂コ一 ン型の場合に、接触円筒駆動型の卷返機では、卷 玉の大径側子小径側間の、表面速度に差があるた めに起るスリップによつて、總毛垃立たりバー ントヤーン（摩損系）を生じ勝であるが、てれら は單に接触する両物体に相対的摺動運動があるた めのみにのみ惹起されるものではなく、両者の接 触圧力之 $\tau_{\mathrm{2} 2}$ 亿概当する回転抵抗之、両者の摩擦 並㳵耗特性に関係するものである。從つて軸受 として無給油軸承（ $\mu_{\mathrm{s}}=0.05 \sim 0.3 ）$ を使用する のと、球軸承（ $\mu_{\mathrm{s}}=0.01 \sim 0.03 ）$ を使用するので は、系の摩耗、毛犲立に與える影響は数倍の差異 があり、スリップの度合よりもむしろプレドミナ ントに考えねばをらない QT 窇返機が平行チ 一ズ存るに係らす毛犽立の多いのは、大牛上記の 事情によるのであつて、クレードルやスピンドル の設計が、卷返機による糸の品質の向上飞重大度 る影響を及ばすものであるてとを立証している。 又ドラム材質に関して同樣の問題があるが、後報 にて詳述する予定である。

$\left.\boldsymbol{\tau}_{\mathrm{d}}\right)$ 糸の旋轉によつて生ずる張力 : $:^{(5)}$ 宾氣抵抗 等を無視した場合の張力 $\boldsymbol{\tau}_{\mathrm{d} 1}$ は(第 4 図参照)

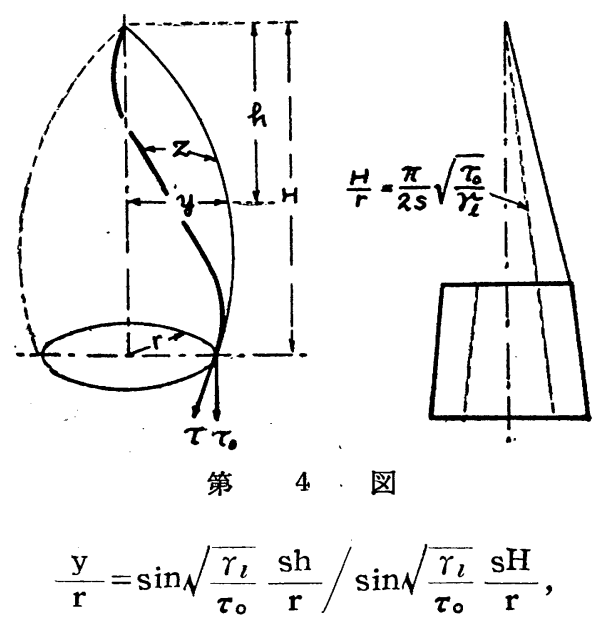

であるから

$$
\begin{aligned}
\tau_{\mathrm{d} 1} & =\tau_{0}\left(V \overline{1+\mathrm{y}^{\prime 2}}-1\right) \mathrm{h}=0 \\
& \fallingdotseq V \overline{\tau_{0} \gamma_{l}} \mathrm{~s} / \sin \sqrt{\frac{\gamma_{l}}{\tau_{0}}} \frac{\mathrm{Hs}_{\mathrm{s}}}{\mathrm{r}},
\end{aligned}
$$

となる。て $\tau_{\mathrm{d} 1}$ を最小炡する條件は

$$
\sqrt{\frac{r_{l}}{\tau_{0}}} \frac{\mathrm{Hs}}{\mathrm{r}}=\frac{\pi}{2}, \frac{3 \pi}{2}, \frac{5 \pi}{2}, \cdots, \cdot
$$

であつて、ての時には

$$
\tau \text { d1. } \min =\sqrt{\tau_{0} \gamma_{l}} \mathrm{~s},
$$

である。又

$$
\sqrt{\frac{r_{l}}{\tau_{0}}} \frac{\mathrm{Hs}}{\mathrm{r}}=\pi, 2 \pi, 3 \pi,
$$

となる時には、卷戻系は瞬間的に非常に大きな施 転曲線を描いたり、切れたりして不安定となる。 一般に卷玉の幅 $l$ が長く系愿 $\mathrm{r}_{2}-\mathrm{r}_{1}$ が厚い場 合には、一結局ラーヂパツヶージでは、かねる 不安定狀態をとる局部的條件を避け難くをる。卷 戻が終始安定となるためには、卷玉のいたるとて ろで (17) 式の左辺の項が $\pi$ より小さいととが 必要で、この條件を満足させるためには、Hが最 大の場合に $\mathrm{r}$ を出來るだけ大きくするとと、つ まりコーン常がよいてとになる。從つてコーン卷 の芯管の傾斜角は、この意味においては出來るた け大をい方がよいが、他方後述の如く卷系速度の 変化とか、スリツプの問題や、容積が大さい、型 崩れや綾はづれし易く友る傾向がある。前揭第 2 図中のMNQR S の諸型の優劣を比較すると、一 般にM型が最も良く、以下N Q R S の順に、解離 の不安定や型崩れ等を起す可能性が多くなり、M 型中では $\mathrm{M}_{3}$ 型が多くの場合最も良い。

精紡管糸（第 2 図S 型）を高速度に卷㞍す場合 凤も同樣の注意が必要で、管糸頂と糸案內口とは 從來は旋轉胍の牛節程度或はそれ以上隔てるてと が慣習となつていたが、管禾下端に至るまでの間 に不安定狀態のないよう、をるべく近接する方が よし

次に系の旋転に対する空氣抵抗を考慮すると

$$
\tau_{\mathrm{d} 1 \mathrm{~d} 2} \mathrm{z} / \mathrm{dh} 2=\mu_{\mathrm{asy}} / 2 \pi \mathrm{r}
$$

を解いて

$$
\tau_{\mathrm{d} 2} \doteqdot \tau_{\mathrm{d} 1}\left\{\nu \overline{1+\left(\mu_{\mathrm{a}} \mathrm{SH} / \tau_{\mathrm{d} 1}\right)^{2} / 25}-1\right\} \cdots
$$

を得る。一般的條件では $\tau$ d 2 は左程大きな值とは なら烄、いがての值を出來得る限り小さくする方 法は、Hを出來るだけ小さくするより外にはな ん。てれは前節の結論と調和する。

$\tau_{\mathrm{e}}$ ）重力に原因する張力： 糸が垂值に懸垂さ れている場合の張力增加量は

$$
\tau_{\mathrm{e} 1}=r_{l} \mathrm{H},
$$

である。水本に懸垂されている場合には 


$$
\tau_{\mathrm{e} 2}=\tau_{\circ}\left\{\sqrt{1+\frac{\tau_{\circ}{ }^{2}}{\gamma_{l}{ }^{2}} \cosh \frac{\gamma_{l} \mathrm{H}}{2 \tau_{\circ}}}-1\right\},
$$

である。前者は一般とその值小さく、後者は整経 機等の場命にはかなりの量となる。

$\tau_{i}$ ）他放体上摩擦によつて生ずる張力：摩擦 のために糸が $a \mathrm{rad}$ 屈曲する場合の增加張力は

$$
\tau_{f 1}=\tau_{0}\left\{\exp \left(\mu_{\mathrm{b}} \alpha\right)-1\right\}
$$

となる。張系ワッシャ一の如く、2物体（夫く添 字 I,I ) 間飞力 $N_{t}$ を多つて挿まれている場合 壮

$$
\tau_{f 2} \doteqdot\left(\mu_{\mathrm{bI}}+\mu_{\mathrm{bII}}\right) w_{\mathrm{t}},
$$

となる。球張系裝置等による張力については、そ の安定性の問題と共に一括して張糸裝置として後 報にて論ずるが、参考のため球張系裝置の正常狀 態における張力式のみ揭げておく。

$$
\begin{aligned}
& \tau_{f 3}=\exp \left(\mu_{\mathrm{I}} \alpha\right)\left\{\tau_{0} \exp \left\{\left(\mu_{\mathrm{I}}+2 \mu_{\mathrm{II}}\right) \alpha\right\}\right. \\
& \left.+(0 \sim 1) \mu_{\mathrm{r} \mathrm{w}_{\mathrm{t}}} \cos \alpha+\mathrm{w}_{\mathrm{t}} \operatorname{cosec}(\alpha / 2)\right\}
\end{aligned}
$$

て」で $\mu_{I}, \mu_{\mathrm{II}}$ は夫く糸と外器、系之球間の摩擦 係数である。(第 5 図参照)

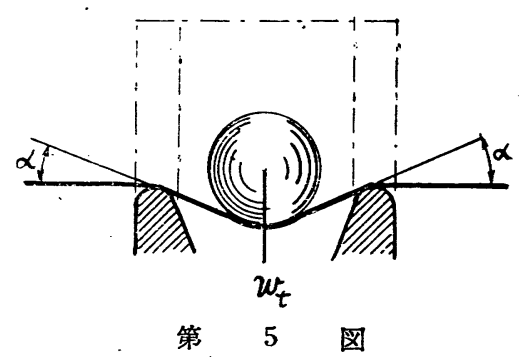

さて (22) 式によつて、系が屈折して摩擦する 場合に生亦る張力堛加は、数值計算してみると

$\begin{array}{lccc}\mu_{\mathrm{b}} & \boldsymbol{\alpha} & \exp \left(\mu_{\mathrm{b}} \boldsymbol{\alpha}\right) \\ 0.3 & 0.2 \pi & 1.06 & \\ 0.3 & 0.5 \pi & 1.64 & \\ 0.3 & 4 & \pi & 43.38 \\ 0.1 & 4 & \pi & 3.51\end{array}-$

となり、第 6 図に示された場合のよ5に、緣のあ る芯管からの卷杘や、精紡木管の取付角度を誤つ たり、卷系愿面や芯管表面の凹凸、結目等に糸が 引㣰つた場合には、張力の変動が甚だしく、異常 張力を毠生し切断する原因となる。有緣卷玉は以

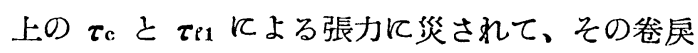
が容易に行われ難的か、容積、型崩れ、包裝等 の要求から緣老必要とするものには、近時第 2 因
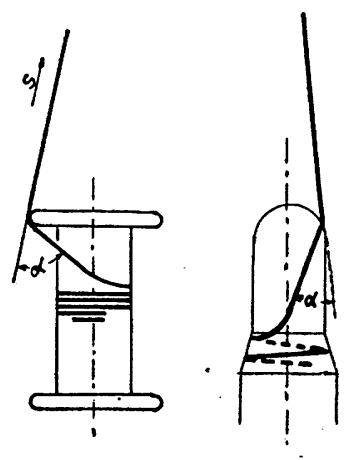

第 6 图

D若〈はRの如き片緣 (Single head bobbin)

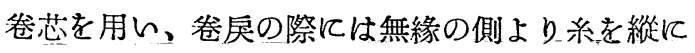
引き出すてとが行われているが、なおて てコーン卷（第 2 四M,N型）に劣る欠点がある。

以上卷玉から糸を卷戻す際に、系に張力を與え、 てれに変動を生ホる主なる原因について通覧して みると（1）糸速に直接大をく関係する因子之 殆んど無関係质因子。（2）張力変動のさけられ ぬ因子と略ヶ一定值を與える因子のあるてとが制 り、（3）卷玉や卷戻の形式によつて除去若くは 安定化する方法、（4）系速を高速化する上溚 慮すべき事柄等が自ら明確と交つた。

運動する糸の張力を実驗的に測定するてとは、 糸の摩擦特性、彈性、密度等の変化や振動等のた めに精密を期し難く、上述の如く原因別に把握す るととは一層困難である。理論的解析はその取扱 方に誤をく省略因子の影響が少をければ、散逸し た実驗值や、正体の不明を結果よりも優る。

\section{5. 卷玉の密度と涯力}

尞玉の密度は、玉染 (Tube dyeing) の場合と 荷造容積が問題となる場合以外は、本來さしてて重 要存事柄では存い。一方系の番手、密度、彈性、 水分、毛犲立、摩擦特性、均整度、張力、然り、 仕上、纎維構造等の䒺質を構成する多樣の因子に 左右されて簡單適確度相関々係を各卷玉樣式につ いて求めることは困難である。系質、張力、尞禾 速度が同一の場合には、一般に

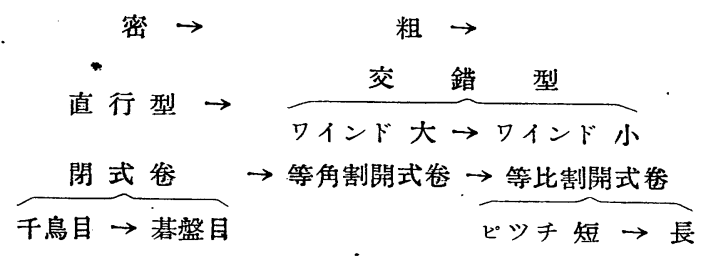


なる傾向がある。密度 $\boldsymbol{\gamma}^{\mathbf{P}}$ の実測例てついてみると $3 / 20 \sim 3 / 50$ 綿系 閉式平行卷 $\gamma_{\mathbf{P}}=0.70 \pm 0.20$

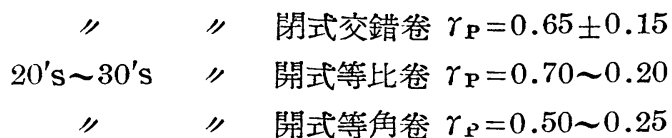
と存り、スフ紷の $\gamma_{\mathrm{P}}$ は約 $10 \%$ 增、人綃系 (120〜 200d) は60～80\%增の值で、人絹は一般に開式等 比卷では0.85〜0.95, 開式等角尞では、0.80〜0.90 位の價と存つている。

今彈性硬度 $K$ 度る牛無限体の上に密接して張ら れた一層の糸列（張力 $=\mathrm{r} \tau$ 。）上に、垂直荷重 $\mathrm{P}$ が加つたときの、夈の変位量性、 $\mathrm{P}$ 着力点を $x$ 軸の原点とすれば、（第 7 因）

$$
\mathrm{m} \tau_{\circ} \mathrm{d}^{2} \mathrm{u} / \mathrm{d} x^{2}-K \mathrm{u}=-\mathrm{P} \leftrightharpoons-\tau_{\mathrm{v}} / \mathrm{r}_{2},
$$

を解いて

$$
\mathrm{u}=\frac{1}{2 \mathrm{r}_{2}} \sqrt{\frac{\tau_{0}}{K \mathrm{~m}}} \exp \left(-\sqrt{\frac{K x^{2}}{\mathrm{~m}_{\tau_{1}}}}\right)
$$

を得る。Pを $x= \pm 1 / \mathrm{m}, \pm 2 / \mathrm{m}, \pm 3 / \mathrm{m} \cdots \cdots$ の位。 置に重盢したときの $\mathbf{u} \rightarrow \mathrm{u}_{\mathrm{s}}$ は

$$
\mathbf{v}_{\mathrm{s}}=\frac{1}{2 \mathrm{r}_{2}} \sqrt{\frac{\tau 0}{K \mathrm{~m}}} \operatorname{coth}\left(\frac{1}{2} \sqrt{\frac{K}{\mathrm{~m}^{3} \tau_{0}}}\right),
$$

となる。ての $\mathbf{u}_{\mathrm{s}}$ よつて、系の彈性、張力、ピッ チと密度間の関係を求めることが出來る。

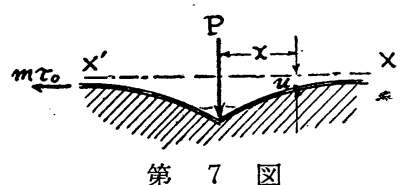

参玉內の压力分布や、芯管の受ける外压力は今 少し簡單に

$$
\mathrm{p}=\int_{\mathrm{r}}^{\mathrm{r}_{2}}\left(\tau_{\mathrm{t}} / \tau\right) \mathrm{dr},
$$

と考えてよい。直行卷、交錯等角类では $\tau_{\mathrm{t}}$ は $\mathrm{r}$ 関係存く一定であるから

$$
\mathrm{p}_{\mathrm{R}}=\tau_{\mathrm{t}} \log \left(\mathrm{r}_{2} / \mathrm{r}\right)=\tau \cos \beta \cdot \log \left(\mathrm{r}_{2} / \mathrm{r}\right)
$$

となる。等比卷では

$$
\cos \beta=2 \pi \nu \mathrm{r} / \sqrt{(2 \pi \nu \mathrm{r})^{2}+l^{2}},
$$

であるから

$$
\mathrm{p}_{\mathrm{P} 1}=\tau\left\{\sinh ^{-1}\left(2 \pi \nu \mathrm{r}_{2} / l\right)-\sinh ^{-1}(2 \pi \nu \mathrm{r} / l)\right\},
$$

と度る。然し実際は $\beta$ の左程大きく変化しない範 囲に限られるから、(29) 式の結果と大差はない。 等比卷の卷返機では、系の張ナてが、卷玉牛径 $\mathrm{r}$ 比例して增大する替䒺速度によつて增大する場合 が多く、張力が

$$
\tau=\tau_{\mathrm{r}} \mathrm{r}
$$

によつて與えられる場合の圧力は、

$$
\begin{aligned}
& \mathrm{p}_{\mathrm{P} 2}=\int_{\mathrm{r}}^{\mathrm{r} \frac{\tau_{\mathrm{r}} \mathrm{rdr}}{\sqrt{\mathrm{r}^{2}+(l / 2 \pi \nu)^{2}}}} \\
& =\tau_{\mathrm{r}}\left\{\sqrt{\mathrm{r}_{2}^{2}+(l / 2 \pi \nu)^{2}}-\sqrt{\mathrm{r}^{2}+(l / 2 \pi \nu)^{2}}\right\},
\end{aligned}
$$

となる。一般の狀態では

$$
\mathrm{p}_{\mathrm{R}}<\mathrm{p}_{\mathrm{P} 1}<\mathrm{p}_{\mathrm{P} 2}
$$

となるが、芯管の軽量化、帣玉の安定化內部應力 の均一化のためには、同一の が小さい程よい。等比卷は $\sin \beta$ 㒹が $\mathbf{r}$ の增加に つれてか度り減少し、後述の如く尞玉の安定性を 害する欠点があるが、卷玉面上の系の分布が常に 均一である特長がある。等角卷は誇張して示す之 第 8 図の如く、差動裝置(Differential motion, Ribbon breaker) が度い場合にはか子り激しく

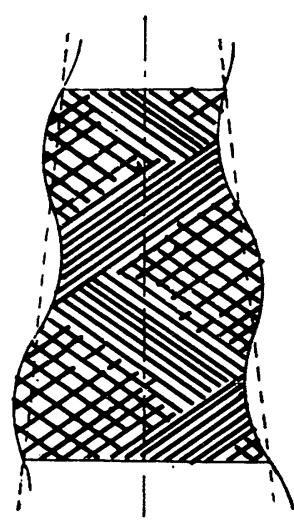

第 8 目 表面に凹凸を生し、系の尞 戻張力に少しではあるが不 同を與え、回転に際して振 動する欠点があるが、卷玉 內の應力分布が各方向均一 的で、等比卷より安定性の ある大型卷玉を形成し易い 特長がある。

\section{6. 卷玉の型崩れ}

最初に土圧論の擁壁の如 く、卷玉內の滑り面 $\overline{\mathrm{OB}}$ に おりる压力に原因する崩壞 現象を考える(第 9 因参照)。簡單のためと、部分 的崩壞をも考えるために、兊玉は直線狀に無限に 続いているものとする。卷玉の端面 $\overline{\mathrm{A}^{\prime}}$ は、中心 軸 $\overline{\mathrm{O}^{\prime}}$ と直交し、Fなる力が作用するものとする。 滑り面 $\overline{\mathrm{OB}}$ は、中心軸 $\overline{\mathrm{OO}^{\prime}}$ とき角をなして交り、 面上飞働く內部應力の牛径方向の分力を $\mathrm{P}$ 、中心 
軸方向の分力を $\mathrm{Q}$ 滑面に働く反作用 $\mathrm{R}$ が滑面の法 線とをす內部摩擦角を $\mathbf{R}$ とする。滑り面とは滑り

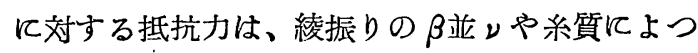
てかなり変化するので、一應零として無視して安 全側に計算する。以上の力が互に本衝する爲には、

$\mathrm{F} \cos \vartheta-\mathrm{P} \sin \vartheta-\mathrm{Q} \cos \vartheta+\mathrm{R} \sin \theta=0$, (35a)

$\mathrm{F} \sin \vartheta+\mathrm{P} \cos \vartheta+\mathrm{Q} \sin \vartheta-\mathrm{R} \cos \theta=0,(35 \mathrm{~b})$ なるてと要する。て」でPは $\overline{\mathrm{AA}^{\prime}}\left(\mathrm{r}_{2} \sim \mathrm{r}_{1}\right)$ 間で （29）式を皘分して

$$
\begin{aligned}
& P=\tau_{t}\left\{\left(r_{2}-r_{1}\right)\left(r_{2}-3 r_{1}\right) / 4+\left(r_{1}^{2} / 2\right) \log \right. \\
& \left.\left(r_{2} / r_{1}\right)\right\} \cot \vartheta=K_{1} \cot \vartheta, \cdots \cdots \cdots \cdots \cdots \cdots(36)
\end{aligned}
$$

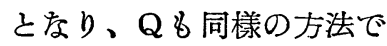

$\mathrm{Q}=\boldsymbol{\tau}_{l}\left(\mathrm{r}_{2}-\mathrm{r}_{1}\right)^{2} \cot \vartheta=\mathrm{K}_{2} \cot \vartheta$,

が得らるる。以上 4 式から

$$
P=\frac{\tan \vartheta\left(K_{1}-K_{2} \tan \theta\right)-\left(K_{1} \tan \theta+K_{2}\right)}{\tan \vartheta(1+\tan \theta \tan \vartheta)},
$$

となり、 $\mathrm{P}=0$ 度るためには

$$
\tan \vartheta=\frac{{ }^{-} K_{1} \tan \theta+K_{2}}{K_{1}-K_{2} \tan \theta}
$$

なることが必要である。又 $\vartheta \pi / 2$ なるためには

$$
\tan \theta \geqslant \mathrm{K}_{1} / \mathrm{K}_{2} \doteqdot \tau_{\mathrm{t}} / 4 \tau_{l},
$$

と存るから

$$
\begin{aligned}
& \tan \theta=0.25 \text { のとき } \tau_{\mathrm{t}} \doteqdot \tau_{l} \text { 郎ち } \beta \doteqdot 45^{\circ}, \cdots(41 \mathrm{a}) \\
& \tan \theta=0.50 \text { とをき } \tau_{\mathrm{t}} \doteqdot 2 \tau_{l} \text { 即ち } \beta \doteqdot 27^{\circ}, \cdots(41 \mathrm{~b})
\end{aligned}
$$

であるべき事を意味している。先に無視した滑り 面における抵抗力は、 $\beta$ が大である程大であるか ら、実際必要存卷付角 $\beta$ は上記の值より幾分小さ くてょいてとになるが、いづれにしても卷玉が安 定するための卷付角はかなり大をいてとが必要で あつて、又大きい程よいてとが判る。

以上は卷付角が一定の場合であつたが、等比卷 の場合には、卷玉牛径 $\mathrm{r}_{2}$ が增大すると共に $\beta$ は漸 次小さく校り、(40) 式の $\mathrm{K}_{1} / \mathrm{K}_{2}$ の 值が次第に 不安定の值に近づくため、一定度を越えた時に卷 玉が自然崩壊する現象が実驗せられている。

卷玉の端面は芯管に対して銳角である程、滑り 崩壞に対して安定であるから、第 2 园中の $M_{1}$, $\mathrm{M}_{2}$ ，Q型よりは $\mathrm{M}_{3}, \mathrm{M}_{1}$ 型がよく、N.R 型は一 層堅牢である。-

次に卷玉がその軸芯方向の外力によつて、系層
面に添うて滑りの発生する場合を論ずる。

（第10図参照）芯軸方向の外力Qは滑り発生の 際は

$\mathrm{Q}=2 \pi \mathrm{r} l \sqrt{1+\tan ^{2} \theta \mathrm{c}} \mathrm{p}(\tan \theta-\tan \theta \mathrm{c})$

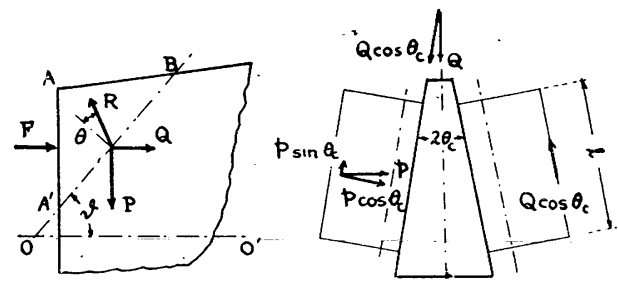

第 9 図第 10 図

となるから、コーン卷の傾斜角 $\theta \mathrm{c}$ は、卷玉の內 部摩擦角 $\theta$ より出來るだけ小さんここが必要であ る。一方內压力 $\mathrm{p}$ との意味においては、杀の强 力等に影響のない限り、大きい方がよい事が制る。 然し(17)式の條件をさけるためには、 $\theta \mathrm{c}$ は度 るへく大きいととを、特に芯管の近傍においては、 要求せられる。從つて卷層のコーン角度が第 2 目 $\mathrm{Q}$ 型の如く、その厚さによつて変化する形式は、 一般に好ましくない。

\section{7. 結語}

卷返機の生產原料であつて又目的物である尞玉 の一般的形狀之その基本的要件について若干の考 察を試み、特に卷玉を卷戻する際の杀の張力とそ の変動性、糸速に関する影響や、卷玉內の密度圧 力分布や安定性について 各因子間の関係を求め た。もとより多種多樣有途に対應する卷玉の要 件を一ß些細に檢討解說するてとは本意ではない が、織布準備機として卷返機の生產対象とする卷 玉について必要とし不明を基礎的理論は明らかに なつた。てれらの結果を罕玉の各型式に適用して 各論するととも省略したが、所論の一般的帰結は 容易に求められよ5。

一般的結論として卷玉は必要てして充分なる傾 斜角を子つた円錐狀に系層を形成し、卷付角の比 較的大き高交錯尞とし、系は縱方向より引き出す ことが望ましく、この際生する系の旋転による張 
力並にその変動に対して、適当委寸法比や系速等 を撰ばねばをらをい。これらに必要な関係式等は 殆んど補つてある。

生產の目的と素材を連結する手段については、 次報より逐次述べるととっしたい。本法に記載さ れた解析計算は、レづれも一般の初等的求積解法 の範囲に属するので、演算の展開取扱等は立式の 思想や結果の意義につんての說明等と共に省略し たてとを峟恕されたい。又実驗值との対比や由來 を述べるとと等も割愛した。

\section{8. 記 号}

$\mathrm{C}=$ 番手,

$\mathrm{F}=$ 卷玉端面に働〉應力 $(\mathrm{gr})$,

$\mathrm{g}=$ 重力の加速度,

$\mathrm{H}=$ 懸垂糸の長さ、旋転糸の高さ $(\mathrm{cm})$,

$\mathrm{h}=\mathrm{H}$ rc関する座標,

$\mathrm{K}_{1}, \mathrm{~K}_{2}=(36)$, (37) 式で與えられる係数,

$\mathrm{k}_{\mathrm{p}}=$ 卷玉の慣性回転牛径 $(\mathrm{cm})$,

$l=$ 綾振幅 $(\mathrm{cm})$,

$\mathrm{m}=$ 卷玉表面糸列のピツチ (本/ $\mathrm{cm})$,

$\mathrm{P}=$ 卷玉牛径力向に加わる力 $(\mathrm{gr})$,

$\mathrm{p}=$ 卷玉牛径方向分布压力 $\left(\mathrm{gr} / \mathrm{cm}^{2}\right)$,

$\mathrm{p}_{\mathrm{R}}=$ 交錯等角卷の $\mathrm{p}$,

$\mathrm{p}_{\mathrm{P}}=$ 交錯等比卷の $\mathrm{p}$,

$\mathrm{Q}=$ 卷玉芯軸方向應力 $(\mathrm{gr})$,

$\mathrm{R}$ =卷玉內滑面上飞作用する反作用 $(\mathrm{gr})$,

$r_{1}=$ 卷玉內牛径 $(\mathrm{cm})$,

$r_{2}=$ 卷玉外牛径 $(\mathrm{cm})$,

$r=$ 卷玉牛径座標 $(\mathrm{cm})$,

$r_{\mathrm{s}}=$ 芯軸の牛径 $(\mathrm{cm})$,

$\mathrm{S}=$ 糸速 $(\mathrm{cm} / \mathrm{sec})$,

$t=$ 時間 $(\mathrm{sec})$,

$\mathrm{u}=$ 卷玉表面の牛径方向変位量 $(\mathrm{cm})$,

$w_{P}=$ 卷玉單重 $(\mathrm{gr})$,

$\mathrm{w}_{\mathrm{t}}$ 二糸を挿む力 $(\mathrm{gr})$, $x=$ 突玉表面上の座標 $(\mathrm{cm})$,

$\mathrm{y}=$ 旋転系の旋転牛径座標 $(\mathrm{cm})$,

$\mathrm{z}=$ 空氣抵抗几よる旋転遅れ座標 $(\mathrm{cm})$,

$\boldsymbol{\alpha}=$ 糸の屈折角 ( $\mathrm{rad}$ ),

$\beta=$ 糸の卷付角 ( $\mathrm{rad}$ ),

$\gamma_{\mathrm{c}}=$ 系線密度 $(\mathrm{gr} / \mathrm{cm})$,

$\gamma_{\mathrm{c}}=$ 糸の密度 $\left(\mathrm{gr} / \mathrm{cm}^{3}\right)$,

$\gamma_{\mathbf{P}}=$ 卷玉の密度 $\left(\mathrm{gr} / \mathrm{cm}^{3}\right)$,

$\mathrm{K}=$ 卷玉彈性硬度 $\left(\mathrm{gr} / \mathrm{cm}^{2}\right)$,

$\mu_{\mathrm{a}}$ 摩擦係数. (糸/空氣) (dyne sec),

$\mu_{l}=$ 摩擦係数. (系/芯管緣禾道等),

$\mu_{\mathrm{s}}=$ 摩擦係数. (芯管/芯軸) (芯軸/軸受),

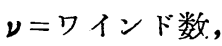

$\theta=$ 能玉內部摩擦角 $(\mathrm{rad})$,

$\theta_{\mathrm{c}}=$ ニーン傾斜角 ( $\mathrm{rad}$ ),

$\vartheta=$ 卷玉內滑り面の中心軸之なす角（rad）,

$\tau_{\mathrm{a}}=$ 糸の離脫 $\{$ 飞要する張力 $(\mathrm{gr})\}$,

……以下大括弧內字们省略す，

$\tau_{\mathrm{b}}=$ 糸の加速一，

$\tau_{\mathrm{c} 1}=$ 卷玉の回転一,

$\tau_{\mathrm{c} 2}=$ 芯軸の回転 - ,

$\tau \mathrm{d} 1=$ 真空中の糸の旋転一,

$\tau_{\mathrm{p} 2}=$ 空氣之系の旋転一,

$\tau_{\mathrm{e} 1}$ 二鉛直に嚺垂するため一，

$\tau_{\mathrm{e} 2}=$ 水本に㲘垂するため一，

$\tau_{\ell 1}=$ 他物体之糸の摩擦一,

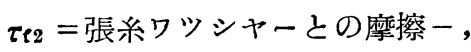

$\tau_{\mathbf{0}}=$ 張力の初期值 $(\mathrm{gr})$,

$\tau_{\mathrm{t}}, \tau_{\mathrm{b}}=$ 夫ょ尞玉內糸張力の円周並に母線方向分

力,

$\tau_{\mathrm{r}}=\mathrm{r} \ll$ 比例する張力の比例常数. $(\mathrm{gr} / \mathrm{cm})$,

$\therefore=$ 一般張力 $(\mathrm{gr})$

註

(4) 本誌Vol. 3, No. 10, '50, PP 18/22.

(5) 例えば Bergmann. Die Spinnerei, Berlin, '31.

(6) "Where to locate the supply." Textile .World. 147 P.154. 